\title{
Effect of the aggregate grading on the concrete air permeability
}

\author{
C. Argiz ${ }^{\mathrm{a}, \mathrm{b}}$, M.A. Sanjuán ${ }^{\mathrm{c}} \bowtie$, R. Muñoz-Martialay ${ }^{\mathrm{a}}$ \\ ${ }^{a}$ Instituto de Ciencias de la Construcción Eduardo Torroja IETcc-CSIC, (Madrid, Spain) \\ ${ }^{b}$ Universidad Politécnica de Madrid UPM (Madrid, Spain) \\ ${ }^{\mathrm{c}}$ Instituto Español del Cemento y sus Aplicaciones -IECA (Madrid, Spain) \\ \masanjuan@ieca.es
}

\begin{abstract}
Great durability problems are being found in concrete structures related to the penetrability of aggressive agents through the concrete (ie. chloride penetration, sulphate attack, carbonation, freezing and thawing, and so on). Air permeability coefficient is used as an effective tool to estimate the potential durability of concrete structures due to its direct relation with the microstructure and the moisture content.

This paper discusses the effect of the aggregate grading and water/cement ratio on the air permeability coefficient. An aggregate grading with more sand than coarse aggregates has resulted more beneficial from the point of view of concrete air permeability. This fact can be attributed to a denser skeleton formed by the finer aggregates. With fine aggregates, the higher water/cement ratio, the lower air permeability. However, the contrary was found with coarse aggregates. Overall, a temperature increase from $20^{\circ} \mathrm{C}$ to $60{ }^{\circ} \mathrm{C}$ during preconditioning led to a $\mathrm{D}_{\text {air }}$ increase of $40-80 \%$.
\end{abstract}

KEYWORDS: Air Permeability; Aggregate grading; Concrete durability

Citation/Citar como: Argiz, C.; Sanjuán, M.A.; Muñoz-Martialay, R. (2014). Effect of the aggregate grading on the concrete air permeability. Mater. Construcc. 64 [315], e026 http://dx.doi.org/10.3989/mc.2014.07213.

RESUMEN: Efecto de la granulometría de los áridos en la permeabilidad al aire del hormigón. Se han encontrado una gran cantidad de problemas de durabilidad de estructuras de hormigón relacionados con la penetración de agentes agresivos externos (es decir, penetración de cloruros, ataque por sulfatos, carbonatación, hielo-deshielo, etc.). El coeficiente de permeabilidad al aire se utiliza como una herramienta eficaz para estimar la durabilidad potencial de las estructuras de hormigón debido a su relación directa con su microestructura y contenido de humedad.

Se discute el efecto de la gradación de los áridos y relación agua/cemento en el coeficiente de permeabilidad al aire. Con áridos más finos que gruesos, el resultado es más beneficioso, lo que se atribuye a que la arena forma un esqueleto más denso. Con áridos más finos, al aumentar la relación agua/cemento, disminuye la permeabilidad al aire; pero con áridos más gruesos se ha observado lo contrario. Cuando se pre-acondiciona de $20^{\circ} \mathrm{C}$ a $60{ }^{\circ} \mathrm{C}$, se produce un aumento del $\mathrm{D}_{\text {air }}$ del $40-80 \%$.

PALABRAS CLAVE: Permeabilidad al aire; gradación de los áridos; durabilidad del hormigón

Copyright: (C) 2014 CSIC. This is an open-access article distributed under the terms of the Creative Commons Attribution-Non Commercial (by-nc) Spain 3.0 License.

\section{INTRODUCTION}

Long-time performance of concrete is considered currently as an important topic which has promoted an increasing study of the parameters related to its durability and the testing methods for its determination as in the case of air permeability. Compressive strength has been considered for long as the only indicator of durability. However, several authors have demonstrated that air permeability and 
compressive strength are independent properties of concrete $(1,2)$.

Volume of pores in aggregates is normally about $10 \%$ than that of the cement paste. However, its size is considerably larger. Thus, the size and gradation of aggregates in the concrete can have an important effect in its air permeability (3). Moreover, the cement paste-aggregate interface is a week point for microcracking and subsequent increase of air permeability, that is, cracks around aggregates promoted by volume changes of the cement paste increases the concrete air permeability $(4,5)$. As consequence, the permeability of concrete is normally about 100 times greater than the permeability of cement paste (6). Also, it has been reported that air entrainment increases air permeability (7).

Therefore, factors related to the production of concrete affect significantly its air permeability, i.e., mix proportioning (aggregate grading), casting and so on. In particular, the distribution of sizes of aggregates, cement and additions influences as well as water-cement ratio and degree of hydration on the concrete air permeability. The packing of all these components will result in a more or less presence of voids to refill by hydration products, particularly in the interfaces between the aggregate and paste $(8,9)$. The increase of air permeability with temperature is attributed to dilation of porous structure of the material (10) as result of changes in the microstructure of the calcium-silicate-hydrate reaction product (11).

Consequently, apart from the porosity of the cement paste in the concrete, it is also necessary to take into account the presence of aggregates which are sometimes not randomly distributed, and the transition zone between these and the cement paste.

In the present work, the objective is to study the influence of the aggregate grading in the concrete mix on its air permeability.

\section{EXPERIMENTAL}

\subsection{Mix Design}

Concrete specimens of $\varnothing 15 \times 30 \mathrm{~cm}^{3}$ made of a common Portland cement CEM I $42.5 \mathrm{~N}$ according to EN 197-1:2011 $(12,13)$ were elaborated using four cement contents of 434, 382, 340 and $307 \mathrm{~kg} / \mathrm{m}^{3}$ and the water content was fixed to $160 \mathrm{dm}^{3}$. Therefore, the water/cement ratios tested were of $0.37,0.42$, 0.47 and 0.52 , respectively. These aggregates were combined in order to get two different gradings: fine and coarse. The sieve analysis is plotted in Figure 1. The aggregate content was: SAND: $628 \mathrm{~kg} / \mathrm{m}^{3}$; PEBBLE: $842 \mathrm{~kg} / \mathrm{m}^{3}$ and GRAVEL: $372 \mathrm{~kg} / \mathrm{m}^{3}$, for the finer grading and SAND: $355 \mathrm{~kg} / \mathrm{m}^{3}$; PEBBLE: $590 \mathrm{~kg} / \mathrm{m}^{3}$ and GRAVEL: $900 \mathrm{~kg} / \mathrm{m}^{3}$, for the coarser one.
The series of sieves used was: $0.15 \mathrm{~mm}, 0.23 \mathrm{~mm}$, $0.60 \mathrm{~mm}, 1.22 \mathrm{~mm}, 2.35 \mathrm{~mm}, 4.70 \mathrm{~mm}, 9.11 \mathrm{~mm}$, $18.60 \mathrm{~mm}$ and $38.10 \mathrm{~mm}$. The principles involved in separation of size by sifting are generally familiar. The grading corresponding to a Fuller aggregate distribution is also shown for comparison. The fine aggregate sample fitted better to the theoretical one of Fuller in the range from 0.60 to $4.7 \mathrm{~mm}$; whereas the coarse one fitted better between 9.11 and 38.1 $\mathrm{mm}$. After a curing at $100 \% \mathrm{RH}$ for 24 hours, the specimens were preconditioned at $20^{\circ} \mathrm{C}$ and $60{ }^{\circ} \mathrm{C}$ in an oven up to constant weight. These concretes can be classified as $\mathrm{C} 30$ according to the concrete European standard EN 206-1.

\subsection{Testing procedure}

The experimental apparatus to measure air permeability in concretes has been described previously $(14,15)$. The air flow, $\mathrm{Q}\left(\mathrm{m}^{3} \cdot \mathrm{s}^{-1}\right)$ was recorded in steady-state conditions and transferred to normal conditions. The air permeability coefficient, $\mathrm{D}_{\text {air }}\left(\mathrm{m}^{2}\right)$, was calculated according to the HagenPoiseuille equation [1] for a laminar flow of a compressible fluid through a porous material:

$$
D_{\text {air }}=2 L \eta \times \frac{Q}{A} \times \frac{P_{o}}{A\left(P^{2}-P_{a}^{2}\right)}
$$

Where the inlet pressures, $\mathrm{P}$, were 128,040; 154,$715 ; 181,390$ and $280,065 \mathrm{~N} \cdot \mathrm{m}^{-2}$ and the outlet and measuring pressures, $\mathrm{P}_{\mathrm{a}}$ and $\mathrm{P}_{0}$ respectively, were equal to the atmospheric pressure. The circular passing surface, A, was of $0.005 \mathrm{~m}^{2}$ and the specimen thickness, L, was $0.07 \mathrm{~m}$. The air at $20{ }^{\circ} \mathrm{C}$ has a value of dynamic viscosity, $\eta$, of $1.810^{-5} \mathrm{~N} \cdot \mathrm{s} \cdot \mathrm{m}^{-2}$.

\section{RESULTS}

Figure 2 shows the air permeability coefficient for the eight concretes studied (four water/cement ratios $\times$ two aggregate gradings). These values correspond to the mean values of six samples which coefficients of variation are shown in Figure 3. It is noticeable that the coefficient of variation does not follow any tendency.

Figure 4 shows the relationship between the air flow rate and the applied pressure ratio $P^{2}-P_{a}^{2}$. The calculated air permeability coefficient, $D_{\text {calc }}$, is obtained from the slope of these straight lines (Figure 5) in which a good correlation has been found in all the cases $\left(\mathrm{r}^{2}>0.99\right)$. Finally, both of the air permeability coefficients that calculated by means of equation [1], $\mathrm{D}_{\text {air }}$, and this one obtained from the slope of Figure $4, \mathrm{D}_{\text {calc }}$, are compared in Figure 6. It is noticeable the good agreement between them in spite of coefficients of variation about $40 \%$ in some cases. 


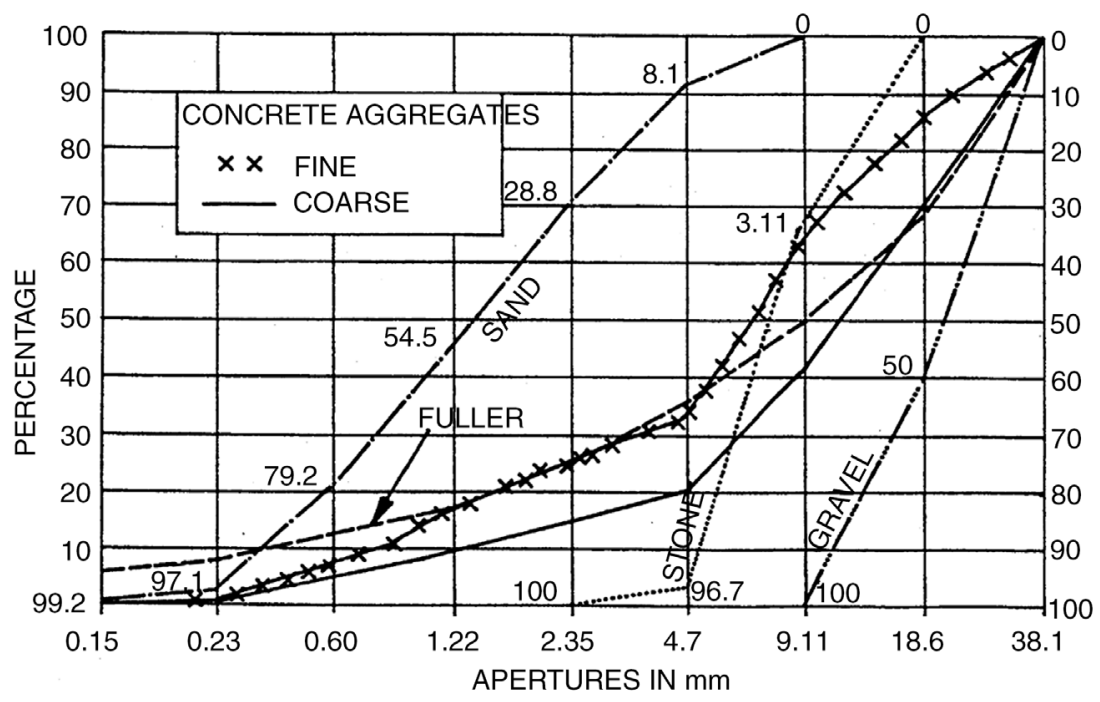

FIGURE 1. Sieve analysis of concrete mix aggregates: coarse and fine grading.

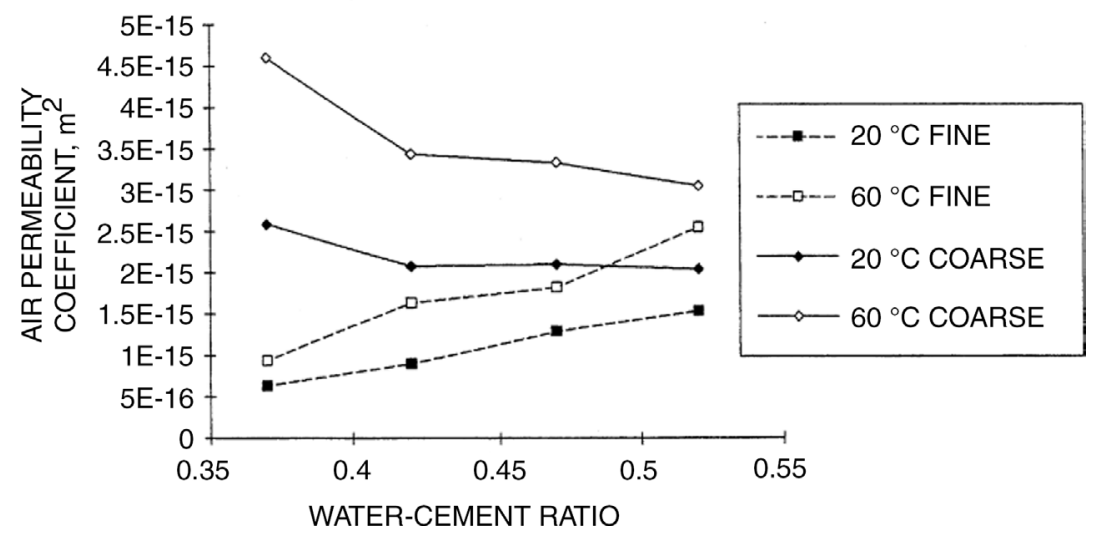

FIGURE 2. Air permeability coefficient versus water-cement ratio for two aggregate gradings and two preconditioning temperatures of $20^{\circ} \mathrm{C}$ and $60^{\circ} \mathrm{C}$.

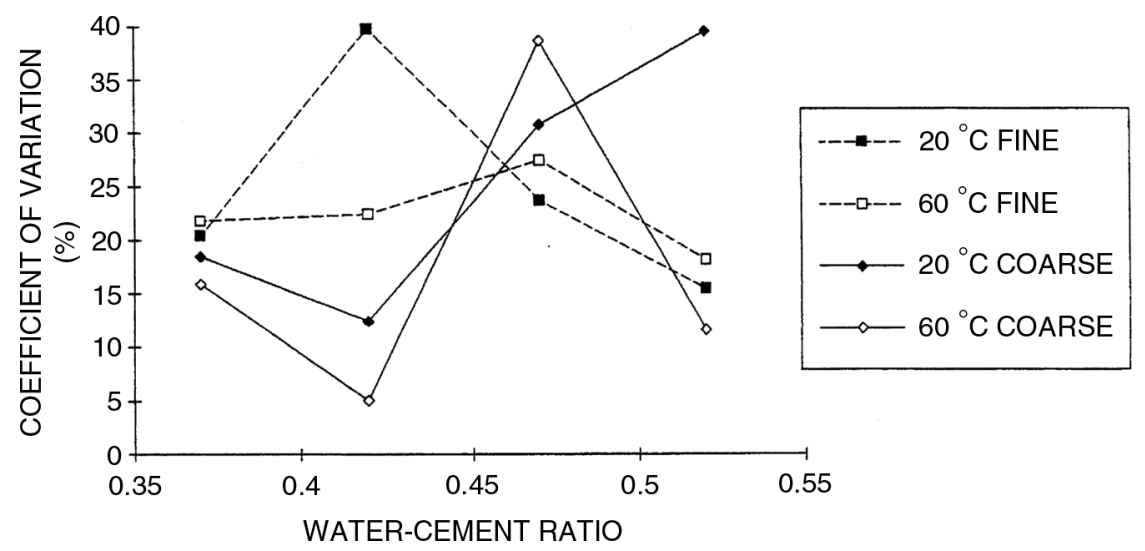

FIGURE 3. Coefficient of variation in percentage of air permeability coeffcient, $\mathrm{D}_{\text {air }}$. 

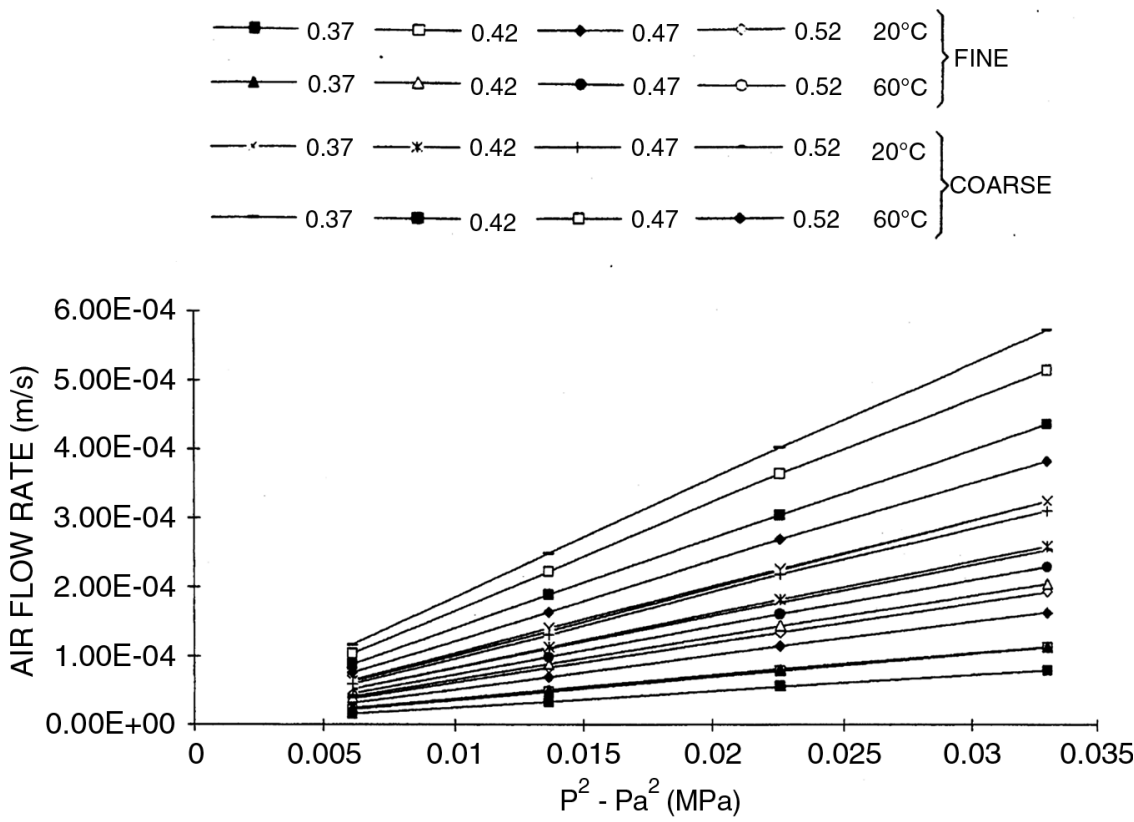

Figure 4. Relationship between the air flow rate and the applied pressure ratio, $\mathrm{P}^{2}-\mathrm{P}_{\mathrm{a}}{ }^{2}$.

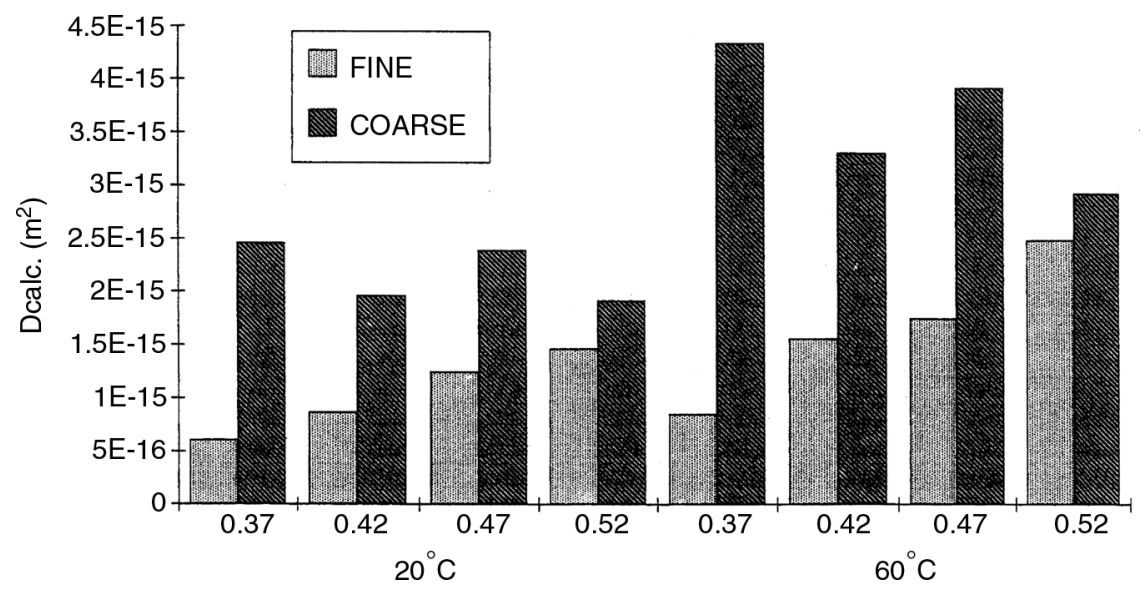

FIGURE 5. Calculated air permeability coefficient, $\mathrm{D}_{\text {calc }}$, at two temperatures and four water-cement ratios.

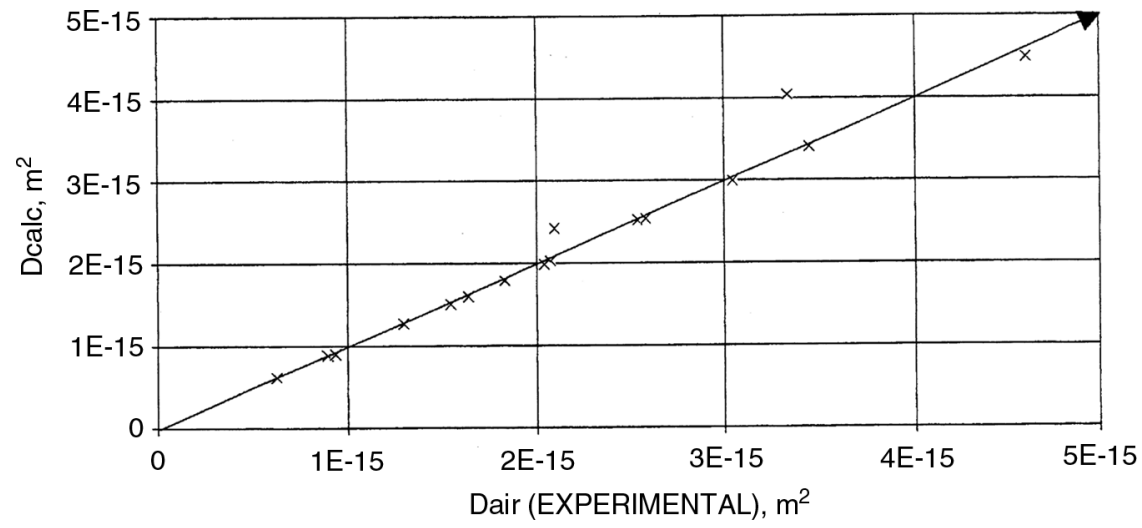

FIGURE 6. Air permeability coefficient, $\mathrm{D}_{\text {air }}$, versus the calculated air permeability coefficient, $\mathrm{D}_{\text {calc }}$. 


\section{DISCUSSION}

As it is well-known, a concrete made using wellgraded aggregates tend to be denser than another one made of poorly-graded aggregates (16), and also air entrained voids increases gas permeability (7). The results indicated that as the proportion of larger size aggregate increases in the mix, the air permeability increases. According to Basheer et al. (17), this fact is a consequence of the increase of the local porosity at the interfacial transition zone and could be explained because there is a reduction in the tortuosity of the flow path, which tends to increase the air permeability, and also because the possibility of the bleed water getting collected below the coarse aggregate increases (17). Cabrera et al. (18) concluded that the shape and surface texture of fines particles has a great impact on concrete and mortar rheology, observable in the increase in water demand in crushed sand compared to natural sand concretes. They also suggest that a $28 \%$ vol. more paste in crushed sand is needed to reduce the interparticle friction. Martín-Morales et al. (19) and Medina et al. (20), studied recycled concrete, where natural coarse aggregate was substituted by recycled construction and demolition waste and ceramic aggregate, respectively. Both of them decided to used natural sand to obtain a good workability in fresh state and a better durability when it is hardened. Nevertheless, the two gradings considered in this investigation do not fit well to the theoretical pattern proposed. The high amount of small aggregates in the fine case leads to a better compactation, and hence, to a more dense and impermeable material as shown in Figure 2.

As expected, $\mathrm{D}_{\text {air }}$ increases with the watercement ratio, but only when a well-graded concrete is tested. On the contrary, the coarse cases present a slightly decreasing of $D_{\text {air }}$ from water-cement ratios of 0.35 to 0.40 which is a consequence of a better compactation when a higher amount of water is used. The absence of fine aggregates (Figure 1) lead to a less workable mixture, and therefore, the final material present a more porous microstructure and then a higher air permeability coefficient (Figure 2). In addition, from watercement ratios of 0.40 to 0.55 , that coefficient remains almost independent of the water-cement ratio. According to Bermejo et al. (21), porosity values are not enough to differentiate air permeability performance of concrete. By contrast, mean pore diameter and pore size distributions have a greater effect on transport mechanisms. However, they found that compressive strength declined where the penetration depth of water under pressure was deepest.

With regard to the coefficient of variation (Figure 3), Bhargava and Banthia (22) recommend to compare permeability data based on ratios due to the large variability normally associated with permeability results. The scatter between the permeability values obtained by Lafhaj et al. (23) did not exceed $30 \%$ and they concluded that this result show that the air permeability testing can be considered as an efficient tool to provide good permeability values.

In the calculated air permeability coefficient from Figure $4, D_{\text {air }}$, the same increasing trend is observed in the fine aggregate grading case, whereas in the coarse case is discontinuous. This behaviour suggests that the $\mathrm{D}_{\text {air }}$ is independent of the water-cement ratio or at least cannot be either estimated accurately or predicted in function of the water-cement ratio.

Results from Figure 5 can be considered as reliable because the theoretical hypothesis of the model used, equation [1], of laminar flow has been checked by Pereira (24). Then, the permeability data constitute an accurate indication of concrete quality (25).

A preconditioning of $20{ }^{\circ} \mathrm{C}$ and water/cement ratio showed the maximum resistance to air permeability (Figure 5). The lowest water/cement ratio provided the lowest porosity when more fine aggregates are used in the concrete mix for both preconditioning temperatures $\left(20^{\circ}\right.$ and $\left.40^{\circ} \mathrm{C}\right)$. However, no specific relationship is seen between air permeability and water/cement ratio when coarser aggregates are used in the concrete mix (Figure 5).

Dried-out concrete at $40{ }^{\circ} \mathrm{C}$ feature the highest air permeability coefficient (Figure 5). This fact can be explained because when the moisture content in the concrete specimen is increased, pores are partially filled and do not allow the air to enter. When coarser aggregates are used, these differences are getting lower and the water content in the concrete specimens influence on the value of the air permeability coefficient, $D_{\text {air }}$, starts prevailing (Figure 5).

The good agreement between the $\mathrm{D}_{\text {air }}$ and $\mathrm{D}_{\text {calc }}$ obtained from the slope of the lines plotted in Figure 4 indicates that the coefficients of variation obtained (Figure 3) can be considered technically acceptable. Only two cases present significant differences, both of them made of coarse grading aggregate and having a water-cement ratio of 0.47 which were preconditioned at $20{ }^{\circ} \mathrm{C}$ and $60{ }^{\circ} \mathrm{C}(16 \%$ and $21 \%$, respectively). The rest of the specimens gave a good agreement.

\section{CONCLUSION}

An excess of fine aggregates with relation to the Fuller curve gives a more dense material than when the excess is of coarse ones. Therefore, in a nonwell graded aggregate distribution it is preferable a higher amount of fine aggregates than coarse ones. However, it is always recommendable to dosage a proper amount either of fine and coarse aggregates in order to get an optimum compactation.

In both cases studied, a preconditioning from $20{ }^{\circ} \mathrm{C}$ to $60{ }^{\circ} \mathrm{C}$ lead to an increase of $\mathrm{D}_{\text {air }}$ ranged between 40 to $80 \%$. In contrast, the air permeability 
coefficient in the fine case increases with the watercement ratio, whereas in the coarse case with less sand content do not follow a clear relationship with this parameter.

Finally, the method for studying air permeability of concrete has given reliable results. However, it is recommended to test several samples in order to get accurate results due to the high coefficient of variation which may be obtained.

\section{ACKNOWLEDGEMENT}

The authors are grateful to the people from the IETcc who helped in this study.

\section{REFERENCES}

1. Hall, C. (1989) Water sorptivity of mortars and concretes: a review. Mag. Concr. Res. 41 [147], 51-61. http://dx.doi. org/10.1680/macr.1989.41.147.51.

2. Pihlajavaara, S.E.; Paroll, H. (1975) On the Correlation between Permeability Properties and Strength of Concrete. Cem. Concr. Res. 5 [4], 321-328. http://dx.doi. org/10.1016/0008-8846(75)90088-5.

3. Soongswang, P.; Tia, M.; Bloomquist, D. (1991) Factors affecting the strength and permeability of concrete made with porous limestone. ACI Mat. J. 88 [4], 400-406.

4. Samaha, H.R.; Hover, K.C. (1992) Influence of microcracking on the mass transport properties of concrete". ACI Mat. J. 89 [4], 416-424.

5. Mills, R.H. (1987) Gas and Water Permeability of Concrete for reactor Building - Small Specimens. Research Report. INFO-0188-1, Atomic Energy Control Board and University of Toronto. p. 126

6. Young, F.J. (1988) A review of the pore structure of cement paste and concrete and its influence on permeability, in: D. Whiting and A. Walitt (Eds.), SP-108: Permeability of Concrete, American Concrete Institute, Detroit, Michigan, $1-18$.

7. Wong, H.S.; Pappas, A.M.; Zimmerman, R.W.; Buenfeld, N.R. (2011) Effect of entrained air voids on the microstructure and mass transport properties of concrete. Cem. Concr. Res. 41 [10], 1067-1077. http://dx.doi.org/10.1016/j. cemconres.2011.06.013.

8. Scrivener, K.L.; Gartner, E.M (1988) Microstructural Gradients in cement paste around aggregate particles, in: S. Mindness, S.P. Shah (Eds.), Bonding in Cementitious Composites, Mat. Res. Soc. Symp. Proc., 114, Cambridge, $77-86$.

9. Scrivener, K.L.; Crumbie, A.K.; Pratt, P.L. (1988) A study of the Interfacial region between cement paste and aggregate in concrete, in: S. Mindness, S.P. Shah (Eds.), Bonding in Cementitious Composites, Mat. Res. Soc. Symp. Proc., 114, Cambridge, 87-88.

10. Choinska, M.; Khelidj, A.; Chatzigeorgiou, G.; PijaudierCabot, G. (2007) Effects and interactions of temperature and stress-level related damage on permeability of concrete.
Cem. Concr. Res. 37 [1], 79-88. http://dx.doi.org/10.1016/j. cemconres.2006.09.015.

11. Valenza II, J.J.; Thomas, J.J. (2012) Permeability and elastic modulus of cement paste as a function of curing temperature. Cem. Concr. Res. 42 [2], 440-446. http://dx.doi. org/10.1016/j.cemconres.2011.11.012.

12. EN 197-1:2011, Cement. Part 1: Composition, specifications and conformity criteria for common cement.

13. Sanjuán, M.A.; Argiz, C. (2012) The new European standard on specifications for common cements UNE-EN $197-$ 1:2011. Mater. Construcc. 62 [307], 425-430. http://dx.doi. org/10.3989/mc.2012.07711.

14. Sanjuán, M.A.; Muñoz-Martialay, R. (1995) Influence of the age on air permeability of concrete. J. Mater. Sci. 30 [22], 5657-5662. http://dx.doi.org/10.1007/BF00356701.

15. Sanjuán, M.A.; Muñoz-Martialay, R. (1996) Oven-drying as preconditioning method for air permeability test on concrete. Materials Letters 27 [4-5], 263-268. http://dx.doi. org/10.1016/0167-577X(95)00283-9.

16. Neville, A.M.; Brooks, J.J. (2010) Concrete Technology, p. $464,2^{\text {nd }}$ revised edition, Transatlantic Publishers Group Ltd., London.

17. Basheer, L.; Basheer, P.A.M.; Long, A.E. (2005) Influence of coarse aggregate on the permeation, durability and the microstructure characteristics of ordinary Portland cement concrete. Construct. Build. Mat. 19 [9], 682-690. http:/l dx.doi.org/10.1016/j.conbuildmat.2005.02.022.

18. Cabrera, O. A.; Traversa, L. P.; Ortega, N. F. (2011) Effect of crushed sand on mortar and concrete rheology. Mater. Construcc. 61 [303], 401-416. http://dx.doi.org/10.3989/ mc.2011.55609.

19. Martín-Morales, M.; Sánchez-Roldán, Z.; Zamorano, M.; Valverde-Palacios, I. (2013) Size grading methods to characterize construction and demolition waste for its use in structural concrete. Mater. Construcc. 63 [310], 235-249. http://dx.doi.org/10.3989/mc.2013.mc.06511.

20. Medina, C.; Juan, A.; Frías, M.; Sánchez de Rojas, M. I.; Morán, J. Ma.; Guerra, M. I. (2011) Characterization of concrete made with recycled aggregate from ceramic sanitary ware. Mater. Construcc. 61 [304], 533-546. http://dx.doi. org/10.3989/mc.2011.59710.

21. Bermejo, E.B.; Moragues, A.; Gálvez, J.C.; Fernández Cánovas, M. (2010) Permeability and pore size distribution in medium strength self-compacting concrete. Mater. Construcc. 60 [299], 37-51. http://dx.doi.org/10.3989/mc.2010.50709.

22. Bhargava, A.; Banthia, N. (2008) Permeability of concrete with fiber reinforcement and service life predictions". RILEM, Materials and Structures 41 [2], 363-372. http:// dx.doi.org/10.1617/s11527-007-9249-6.

23. Lafhaj, Z; Richard, G. Kaczmarek, M. Skoczylas, F. (2007) Experimental determination of intrinsic permeability of limestone and concrete: Comparison between in situ and laboratory results. Building and Environment 42 [8], 3042 3050. http://dx.doi.org/10.1016/j.buildenv.2006.07.039.

24. Pereira, V.M.; Carvalho, E.; Bardella, P.S.; Camarini. G. (2008) Fluid-dynamic analysis of the flow in air permeability measurement of mortars prepared with blast-slag furnace Portland cement. Cerâmica 54 [330] 160-166.

25. Paulini, P. (2010) A laboratory and on-site test method for air permeability of concrete. $2^{\text {nd }}$ International Symposium on Service Life Design for Infrastructure. 4-6 October 2010, Delft, The Nederlands, pp. 995-1002. 